\title{
ЯЗЫКОЗНАНИЕ
}

UDC 811.113.5+811.112.2+81'1

Ewa Data-Bukowska

Jagiellonian University in Kraków, Poland

\section{LITERAL TRANSLATION IN THE LIGHT OF THE GRAVITATIONAL PULL HYPOTHESIS: THE CASE OF SENTENCE-INITIAL INDEFINITE NOUN PHRASES IN SINGULAR IN NORWEGIAN-TO-GERMAN AND GERMAN- TO-NORWEGIAN TRANSLATION}

For citation: Data-Bukowska E. Literal translation in the light of the gravitational pull hypothesis: The case of sentence-initial indefinite noun phrases in singular in Norwegian-to-German and German-to-Norwegian translation. Scandinavian Philology, 2021, vol. 19, issue 1, pp. 5-29.

https://doi.org/10.21638/11701/spbu21.2021.101

The present article reports on a study of renditions of sentence-initial indefinite noun phrases (NPs) in singular in Norwegian-to-German and German-to-Norwegian parallel corpus data. It briefly describes the correspondences to such NPs and the translation-induced changes that are made in the structure of the sentences including the phrase. In particular, however, the study focuses on fully congruent correspondences to singular sentence-initial indefinite NPs, i. e., the instances in which the structure is formally copied in translational renditions. Finding out to what extent such sentence initials are preserved in translation allows us to verify the hypothesis about literal translation that pertains to a potential (yet somehow forgotten) translation universal. By referring the conducted study to the framework of the current version of the gravitational pull hypothesis by Sandra Halverson, it becomes possible to position the phenomenon of literal translation in the context of the latest research into bilingual cognition and to find common ground where more traditional contrastive linguistics and translation studies may meet. The analysis generally supports the literal translation hypothesis as the NPs under investigation (classified as highly salient linguistic structures) have been translated into German and Norwegian literally in over $70 \%$. Thus, the gravitational 
pull of the source text structures on the target language is of similar strength. On the other hand, it has been observed that Norwegian is more resistant to using sentence-initial indefinite NPs than German, or that German applies this way of content construal more willingly. In a broader perspective, the research results shed new light on the extent to which the linguistic patterns of the use of the indefinite article in a real text production are similar and entrenched in a bilingual's Norwegian/German representation.

Keywords: literal translation, gravitational pull hypothesis, translation universals, correspondence, indefinite article.

\section{INTRODUCTION}

Norwegian and German are closely related languages showing some clear grammatical similarities. They both are verb-second (V2) languages, which means that they have grammaticalized the position for the finite verb as the second language item in the main clause word order scheme, and as a result allow only one clause element to be placed before the verb. The present article examines a phenomenon that has its roots in this grammatical similarity and pertains to the way sentences are introduced in the two languages in a text [cf. Hasselgård, 1997, 1998, 2004; Altenberg, 1998; Johansson, 2004, 2005]. In the conducted study, the sentence-initial indefinite NP in singular has been chosen as the point of departure in a thorough analysis based on translations.

Conducting research focused on indefinite NPs used as sentence initials was inspired by one of Hilde Hasselgård's recent articles entitled "Sentence-initial indefinite subjects in English and Norwegian" [Hasselgård, 2018]. In this study, the scholar notices that the occurrence of sentence-initial indefinite NPs is untypical in Norwegian because, in this language, a strong preference for 'light' themes may be confirmed [Hasselgård, 2018, p. 98]. Moreover, such uses of the indefinite NP may be seen as peculiar in general, since they express information that is new for the addressee while the sentence opening is prototypically intended for different types of thematic (old, contextually given or already known, predictable or simply recoverable) content. As Quirk et al. [Quirk, Greenbaum, Leech, Svartvik, 1985, p. 1402, after Hasselgård, 2018, p.96] express it, "a certain awkwardness is sensed where the recipient is expected to interpret a theme as entirely new and unconnected with anything previously introduced". Nevertheless, despite this generally accepted regularity, indefinite NPs appear as sentence initials in both English and Norwegian, and the same can be said about German and many other languages. Therefore, the use of this type of phrase is an 
interesting object of study. Their occurrence in language use may seem like a kind of figure [Langacker, 1987, p. 120], i. e., a somehow prominent or salient way of content construal, distinguishing itself from the more typical (prototypical) manners of linguistic expression.

The research by Hasselgård [Hasselgård, 2018] is also inspiring from the perspective of translation studies. The Norwegian scholar notices the fact that " $[t]$ ranslation correspondences of indefinite subjects show that the subject NP is retained in congruent form in the majority of cases, but more changes are made in translations from English into Norwegian than the other way round" [Hasselgård, 2018, p. 93, bold E. D.-B.]. In her other studies [Hasselgård, 1997, 1998, 2004, 2005], she confirms the same observation pertaining to the topical theme as such in translation between the mentioned languages, which, according to her, is "evidence of translationese, i. e., influence from the source language" [Hasselgård, 2004, p. 193]. Moreover, the scholar adds that in spite of grammatical differences between these languages, English and Norwegian translations "to a very large extent preserve the sentence opening of the original” [Hasselgård, 2004, p. 194].

Observations of this kind are not unusual, especially in contrastive corpus studies. Yet, they mostly are conceived concisely among many other more profound research findings. Their common denominator is that they mainly focus on English as related to other languages and imply a kind of "copying" of different types of source text (ST) structures into the target text (TT) - a phenomenon that appears as a drawback of translational activity for some researchers. Studies that zoom in on this particular issue and treat it as an ordinary characteristic of cross-linguistic communication via translation [e. g. Data-Bukowska, 2015, 2019] are clearly underrepresented. Thus, from the point of view of translation research, an intriguing question arises: namely, to what extent are the translators willing to "copy" source text structures in the target text in a situation when grammatical similarities are very obvious between languages, as e. g., it is the case with Norwegian and German? Answering this question appears particularly interesting in the light of the so-called literal translation hypothesis, undergoing a kind of revival in the studies on translation in the recent years and exposing literal renditions as a potential translation universal (see [Halverson, 2015] for a thorough discussion).

Therefore, the aim of the present study is to find out to what extent in Norwegian-to-German and German-to-Norwegian translation the 
source text sentence opening represented by the indefinite NP in singular is subjected to conceptual "copying" while being rendered into the target language, with the purpose of verifying the hypothesis about literal translation. It is believed that, in this way, some information about a potentially universal feature of translations may be revealed. An additional objective is to capture principal changes in the structure of the sentences including such NPs in translation to widen our knowledge of similarities and differences between languages under investigation on the level of conventional content construal [Langacker, 1987]. In the analytical part of the article, these questions are answered on the basis of the translations from the Oslo Multilingual Corpus (the OMC) ${ }^{1}$.

\section{THE LITERAL TRANSLATION HYPOTHESIS}

Vinay and Darbelnet define literal translation as a reversible, grammatically and idiomatically appropriate word-for-word transfer of a source text structure into a target text and see it as a unique, but possible and fully acceptable procedure in translation [Vinay, Darbelnet, 1995, p. 33, 34). According to the literal translation hypothesis, this type of rendition is preferred to other strategies in translation because it seems to be cognitively economic. Applying a less literal solution would simply be more effortful, or could increase the risk that a less equivalent or adequate translation may occur.

The first translation scholar to notice such cognitive economy was Levý [Levý, 1967]. He observed that during the mapping process translators intuitively apply those solutions that are connected with minimal mental effort, i. e., by using the so-called minimax strategy, and literal renditions fit completely within this context. A reference to cognitive economy is also implied in the work of Ivir [Ivir, 1981], who stresses that translators begin the process of establishing equivalence by determining formal correspondences between languages used in translation and opt away from such solutions only when their use becomes impossible. The formal aspect of the mapping is, however, always present in their con-

1 The Oslo Multilingual Corpus (1999-2008), the Faculty of Humanities, University of Oslo. The OMC is a product of the interdisciplinary research project Languages in Contrast (SPRIK), directed by Stig Johansson and Cathrine Fabricius-Hansen, and compiled by the OMC corpus team. More information about the OMC is available at: https://www.hf.uio.no/ilos/english/services/omc/team/. The OMC was accessed 19.7.2019 at: https://tekstlab.uio.no/glossa2/omc4. 
sciousness [Ivir, 1981, p. 58]. In the context outlined here, it also seems important to mention a study by Tirkkonen-Condit [Tirkkonen-Condit, 2005], in which she argues that literal translation is a default translation procedure that is, however, cognitively preferred to others, both by novice and professional translators.

The same line of thought about translation underlies Toury's "law of interference" [Toury, 1995]. The scholar views this procedure as one of the main laws in the translation process, during which "phenomena pertaining to the make-up of the source text tend to be transferred to the target text" [Toury, 1995, p.275]. As Malmkjær [Malmkjær, 1993, p. 287] notices, "the translator normally works with the source text before his very eyes". Therefore, in an actual translation task the semantic representation constituting the core of translation must interact with "the visual text representation of the source text", which may enhance literal renditions.

According to Chesterman [Chesterman, 2011], literal translation is strengthened due to the entrenchment of linguistic patterns occurring in the languages meeting in translation. Such patterns are based on a formal similarity between such languages and pertain to e. g., thematic order, voice, syntactic structure [Chesterman, 2011, p. 27, after Halverson 2015, p.314].

The cognitive basis of this phenomenon makes it a good candidate for a translation universal that occurs in translations independently of the language combinations, which some scholars stress [cf. Schaeffer et al., 2014; Schaefer, Carl, 2014]. In accordance with recent research, only the phenomena that are grounded in human cognitive abilities have a chance to be universally represented in translated language as such. As Chesterman [Chesterman, 2004, p. 10] expresses it, "[t]he immediate causes of whatever universals there may be must be sought in human cognition - to be precise, in the kind of cognitive processing that produces translations".

\section{LITERAL RENDITIONS AS A "DEFAULT" TRANSLATION BY S. HALVERSON}

In a cognitively oriented framework of potential translation universals presented by Sandra Halverson, literal translation is conceived as "default". However, "default" is understood by the researcher in a particular way, i. e., as pertaining to a phenomenon when "TL items or structures 
tend to be chosen faster, more easily and (most likely) more often than others" [Halverson, 2015, p. 315]. According to this approach, particular patterns of meaning construal in translated texts (independently of the language) are cognitively motivated, i. e., they are triggered by "specific characteristics of bilingual representation", among which cognitive salience and entrenchment are of particular importance [Halverson, 2015, p. 315]. It may be then concluded that, within this account, a trigger for literal ("default") translation is some factor of cognitive salience or entrenchment of linguistic structures in the translator's linguistic representation. In this context, literal rendition may be understood as "a translation in which salience or entrenchment effects are deemed acceptable, or are not overridden" (cf. Halverson, 2017, p. 16].

How the factors of salience and entrenchment may be activated in translation has been explained by the Norwegian researcher in her framework of "the gravitational pull hypothesis" presented in her earlier works [Halverson, 2003, 2010] and modified in the recent research [Halverson, 2015, 2017].

\section{THE GRAVITATIONAL PULL HYPOTHESIS}

In her hypothesis, Halverson proposes a model for how a cognitive semantic structure in a bilingual mind enhances the translation process and - ultimately - the shape of the translated language conceived in texts. She describes the hypothesis in its basic form as follows:

[...] in a translation task, a semantic network is activated by lexical and grammatical structures in the ST. Within this activated network, which also includes nodes for the TL words and grammatical structures, highly salient structures will exert a gravitational pull, resulting in an overrepresentation in translation of specific TL lexical and grammatical structures that correspond to those salient nodes and configurations in the schematic network. [Halverson, 2003, p. 218, bold E. D.-B.]

However, as Halverson [Halverson, 2017, p. 12] points out, the current, expanded version of the hypothesis is to a greater extent based on the assumption that linguistic cognition in bi- or multilinguals is different from that in monolinguals, which means that it is assumed to be strictly connected with the mutual interaction of cognitive linguistic structures in the human mind. Applying this perspective in translation studies implies, among other things, that the TL-features are taken into consideration in analyzing translational phenomena to a greater extent. In this way, the hypothesis becomes more dy- 
namic, and its crucial concept of salience is seen as multidimensional. According to the scholar, in the source language category salience is "a true form of cognitive gravity, i. e., a cognitive force that makes it difficult for the translator to escape from the cognitive pull of highly salient representational elements in the source language" [Halverson, 2017, p. 14]. It is the main source of transfer as such structures are preferred in translational renditions. In the target language, on the contrary, it may be more clearly captured by the metaphorical term magnetism, because this term expresses "the idea that in the cognitive search for a target language item, the translator is more likely to be drawn to a target language item with high salience" [Halverson, 2017, p. 14]. Finally, "an additional source of hypothesized translational effects is the nature and strength of links between elements in a bilingual's two languages", which she calls connectivity [Halverson, 2017, p. 14]. "[T] he more established (entrenched) a link is, the more likely it will be activated and used in translation, and vice versa" [Halverson, 2017, p. 15]. Halverson conceives the hypothesis in its new form as follows:

The original gravitational pull hypothesis is now split into three posited sources of translational effects: source language salience (gravitational pull), target language salience (magnetism), and link strength effects (connectivity). However, the basic thrust of the cognitive model remains the same [...] [Halverson, 2017, p. 15].

The notion of salience is complex and, as the Norwegian researcher points out, "can be understood to be related to a number of cognitive phenomena" [Halverson, 2017, p. 13]. Moreover, "it may be impacted by a number of factors, including type of meaning, recency of activation, and various elements of the unfolding discourse representation" [Halverson, 2017, p. 13].

Thus, it can be concluded that the gravitational pull and the literal translation hypotheses are related, and the former, which is wider in its scope, may be applied to verify the latter, providing its better understanding and anchoring in the most recent knowledge about bilingual cognition. The goal seems intriguing as the concept of the gravitational pull has been addressed in corpus studies only in passing.

\section{SENTENCE CONSTRUAL AS A SALIENT LINGUISTIC FEATURE}

As mentioned above, literal translation has always been understood as form-oriented renditions. Therefore, for the purposes of the present study, the term salience will be used to refer to the idea that the linguistic 
form of sentence construal (which, similarly to meaning, is represented cognitively) possesses a particular status in the human linguistic representation. It is assumed in the investigation that such linguistic patterns (of a different kind) are ascribed a great cognitive weight, increasing the likelihood that they will be preserved in translation, particularly if they are based on a formal similarity between languages meeting in translation. However, other factors can also affect salience preference.

The singular indefinite NP occurring in the sentence initial position, which has been chosen as the object of a thorough investigation in this article, shows clear features of prominence. Traditionally, the sentence initial position in the main clause is considered to be the most exposed as it pertains to information through which the message is introduced. As explained in the introduction to this article, the indefinite NP in this position draws the speaker's extraordinary attention to itself in a sentence, because it appears in the place where some thematic information is expected. So, if such uses of NPs in a text are so untypical in Norwegian as Hasselgård [Hasselgård, 2018, p. 98] states, it may be assumed that they represent a salient element within the inventory of linguistic expressions conventionalized in this language - a fact that will enhance the salience effect of the whole sentence construed in a specific manner. The same may be assumed about German, in which the use of the indefinite NP that opens a clause will rather have a marked status.

In the above context, it may be added that from the cognitive perspective, literal translation can also be interpreted in terms of structural priming, which is cognitively basic [Henson, 2009, p. 1060]. This means that when a translator reads a source text structure, a specific element in the target language may be primed due to the close physical (formal) similarity of the prime and probe in his/her memory links [cf. Data-Bukowska, 2019]. In this type of research, it is believed that elements of a similar form have strong links across languages and word order is an important factor in syntactic priming [Hartsuiker, Pickering, Veltkamp, 2004, p. 412]. According to Filipović [Filipović, 2014, p. 215], this is "the most efficient way of organizing multilingual information" in a bilingual (or multilingual) mind. 


\section{THE GRAVITATIONAL PULL CONCEPT IN THE CONTEXT OF CONTRASTIVE STUDIES}

Combining the three sources of translational effects (gravitational pull, magnetism and connectivity) within Halverson's hypothesis may also be important for traditional contrastive studies as it might extend their research perspective and highlight the question about similarities that appear between two languages - an issue that is still an underappreciated aspect of contrastive analyses. In this case, it may be supposed that if some similarities between two (a few) languages indeed exist in the speaker's mental representations, they may be "brought to life" via translation, because they may be displayed by the effect of magnetism. It is e. g., believed that if languages share procedures for building sentences, the use of such procedures in one language may enhance their accessibility in the other [Loebell, Bock, 2003, p. 809; Filipović, 2014, p. 213]. Therefore, it can be expected that the data collected in large language corpora (based on approved translations) may include such "enhanced" structures that are deemed acceptable in the TL, even though they may seem less commonly in use in it. They constitute, however, the inventory of similarities that the two languages meeting in translation possess.

\section{METHODOLOGICAL REMARKS}

German and Norwegian indefinite NPs are very similar in form, particularly if they include indefinite articles occurring only in singular. The indefinite article is the clearest and most unequivocal indicator of indefiniteness, and as such unambiguous to classify. The inflectional forms for this article for Norwegian are: en/ei/et (bokmål) and ein/ei/ eit (nynorsk) and its forms for German are: ein/eine/einen/einer/einem/ eines. They vary depending on the grammatical gender (masculine, feminine, neuter) in both languages. A typical feature for the German forms is the disclosure of the grammatical case - something that the Norwegian items do not express.

The use of the indefinite article within the NP may be assumed to have some similar conditions in both languages as well. It can be nonspecific (describing any member of a class) or generic (describing a typical member of a class) [Faarlund, Lie, Vannebo, 2002, p. 290-292; Hasselgård, 2018, p. 96; Helbig, Buscha, 1988, p. 374-376]. 
In the present investigation, only declarative main clauses with an indefinite NP in the sentence opening were taken into consideration. Single phrases (i. e., not used in a clause) were excluded, along with phrases of the type en/ei/et of / ein/ei/eit of + definite NP / ein/eine/einen/ etc. von + definite NP, classified as including numerals. Moreover, other instances of en/ei/et used as numerals have not been taken into account in the analysis. The same pertains to ein/eine/einen/ etc. in German.

The data for the investigation is derived from two databases included in the OMC: the ge-no-ge sub-corpus and the no-en-ge sub-corpus, both classified as parallel corpora. The former is based on original texts and their translations (German-to-Norwegian, Norwegian-to-German), both fiction and non-fiction. The latter is smaller and less balanced as it includes mainly fictional texts, Norwegian originals and their English and German translations. ${ }^{2}$

The translations collected in these sub-corpora represent the work of competent, professional translators (as opposed to translators with insufficient qualifications), which was an important factor of the investigation. The texts constituting the corpus data were published translations and, as such, had been subjected to editorial revision increasing their acceptability in the target language culture. Therefore, it was assumed that the solutions applied in the texts are representative of the given target text language, just as they represent the source language characteristics. It was also assumed that the analyzed sentences reveal optional changes in translations based on Norwegian and German. As viable options for the initial position in both languages include several clause elements, the translator choosing a particular word order had a range of choices.

The indefinite phrases were retrieved by searching for indefinite articles (in all their forms mentioned above). The search was conducted through the Glossa-browser [Oslo Multilingual Corpus], the application of which was particularly efficient for finding fully congruent correspondences for these language items. Yet, all selected concordances were additionally searched manually by close reading to remove irrelevant language data. The selected concordances were processed with regard to the following, more detailed research questions:

${ }^{2}$ For more information on these corpora see: https://www.hf.uio.no/ilos/english/ services/knowledge-resources/omc/sub-corpora/. 
1. To what extent is the singular indefinite NP in the sentence opening in Norwegian-to-German and German-to-Norwegian parallel corpus data "copied", i. e., rendered by its fully congruent correspondence [Johansson, 2007], in translations and sources?

2. What other elements appear in the sentence initial position as correspondences to the indefinite NP in both types of renditions?

3. What can changes made in the translation reveal about the patterns pertaining to sentence construal in both languages?

The correspondence was understood as "what is observed in a corpus" resulting from a particular translational solution [Johansson, 2007, p.5]. The congruent correspondence was treated as a target language structure that did not differ in form from the source in translation [Johansson, 2007, p. 25]. Yet, for the present study it meant exclusively a "fully congruent" structure, i. e., an indefinite NP in singular rendered by an indefinite NP in singular.

As the OMC is a bidirectional translation corpus, the correspondences to the sentence-initial indefinite NPs in singular were studied in two directions:

in $\mathrm{N} \rightarrow \mathrm{G}$ data, as the German translations of the NP (designated as translations) in the Norwegian original texts and as the German sources of the NP (designated as sources) in translations into Norwegian;

in $\mathrm{G} \rightarrow \mathrm{N}$ data, as the Norwegian translations of the NP (translations) in the German original texts and as the Norwegian sources of the NP (sources) in translations into German.

The formal aspect of the analyzed structures was very clear in the investigation focused on their conceptual copying and preservation in translation. In accordance with the gravitational pull hypothesis, singular indefinite NPs used as sentence initials were conceived as ideal candidates for being chosen more easily and more frequently than others, due to their salience in language use in Norwegian and German. The way of processing the corpus data described above allowed us to see the phenomenon of literal rendition pertaining to the given languages as a result of two translational effects: a) gravitational pull of the source language, and b) magnetism of this language functioning as the target language. It was also possible to draw some conclusions 
on the connectivity of the investigated structures in Norwegian and German.

\section{THE RESULTS}

Table 1 above shows the main findings in the conducted analysis. ${ }^{3}$ In the Norwegian-to-German corpus data, a total of 356 and 588 occurrences of singular indefinite NPs in the sentence initial position was extracted, in translations and sources, respectively. In German-to-Norwegian, the investigated data yielded 539 examples in translations, and 371 in sources. Thus, it may be concluded that sentence-initial indefinite NPs in singular are more frequent in German than in Norwegian original texts (539/356). Moreover, they are more frequent in German sources while translated into Norwegian than vice versa (588/371) a fact that also may indicate that the use of such phrases is more popular in German.

Table 1. The realization of sentence-initial NPs in singular in the investigated data

\begin{tabular}{|l|c|c|c|c|c|c|c|c|}
\hline \multirow{2}{*}{ Correspondence } & \multicolumn{3}{|c|}{$\begin{array}{c}\text { Norwegian-to-German } \\
(\mathrm{N} \rightarrow \mathrm{G})\end{array}$} & \multicolumn{3}{c|}{$\begin{array}{c}\text { German-to-Norwegian } \\
(\mathrm{G} \rightarrow \mathrm{N})\end{array}$} \\
\cline { 2 - 9 } & translations & \multicolumn{2}{|c|}{ sources } & \multicolumn{2}{c|}{ translations } & \multicolumn{2}{c|}{ sources } \\
\hline Fully congruent & 265 & $74.43 \%$ & 395 & $67.17 \%$ & 397 & $73.65 \%$ & 272 & $73.31 \%$ \\
\hline Other & 36 & $10.11 \%$ & 79 & $13.43 \%$ & 9 & $1.66 \%$ & 29 & $7.81 \%$ \\
\hline Definite NP & 9 & $2.52 \%$ & 38 & $6.46 \%$ & 12 & $2.22 \%$ & 8 & $2.15 \%$ \\
\hline $\begin{array}{l}\text { Sentence } \\
\text { transformed }\end{array}$ & 46 & $12.92 \%$ & 76 & $12.92 \%$ & 121 & $22.44 \%$ & 62 & $16.71 \%$ \\
\hline Total & $\mathbf{3 5 6}$ & $\mathbf{1 0 0} \%$ & $\mathbf{5 8 8}$ & $\mathbf{1 0 0} \%$ & $\mathbf{5 3 9}$ & $\mathbf{1 0 0} \%$ & $\mathbf{3 7 1}$ & $\mathbf{1 0 0 \%}$ \\
\hline Excluded & 192 & $35.03 \%$ & 223 & $27.49 \%$ & 160 & $22.88 \%$ & 181 & $32.78 \%$ \\
\hline $\begin{array}{l}\text { Concordances } \\
\text { in total }\end{array}$ & 548 & $100 \%$ & 811 & $100 \%$ & 699 & $100 \%$ & 552 & $100 \%$ \\
\hline
\end{tabular}

${ }^{3}$ Table 1 also includes information pertaining to all occurrences of the indefinite NPs identified in the corpus data and the amount of the concordances that were excluded because they did not fulfill the requirement to be the initial part of a main clause. 
As for the first research question: by completing the inventory of fully congruent correspondences to Norwegian and German singular indefinite NPs in the sentence initial position, clear similarities between these languages were confirmed.

The analysis revealed that $74.43 \%$ of the analyzed Norwegian and $73.65 \%$ of German indefinite NPs were classified as such correspondences in translations, and the rates in the sources were $67.17 \%$ and $73.31 \%$, respectively. Examples presented below show these types of linguistic conceptualizations, in translations - (1) and in sources - $(2)^{4}$.

(1)

Et vindu blir slått opp.

Ein Fenster wird aufgerissen. LSC1N.5.s111

Ein omn til, nr. 32, blir starta, ...

Ein neuer Ofen, Nummer 32, wird in Betrieb genommen, ... KFL1N.1.6.s2

Eine Lampe brannte düster.

En lykt lyste svakt. THH1D.3.s300

Ein kleiner weißer Hund kam aus dem Haus gelaufen, ...

En liten hvit hund kom løpende ut av huset, ... DW1D.2.s240

(2)

Ein Männerchor sang ein Volkslied.

Et mannskor sang en folkevise. DW1TN.3.s273

Eine Straßenlampe über uns war heller, als ich die Sonne je gesehen hatte.

En gatelampe over oss strålte mer intenst enn sola. CF1TN.1.s728

En dissonans er ikke mer uskjønn enn en konsonans.

Eine Dissonanz ist nicht weniger schön als eine Konsonanz. CL1TD.1.3.5.s4

Et øyeblikk efter går døren opp;

Einen Augenblick später geht die Tür auf. EFH1TD.1.s347

4 The abbreviations TN (translated Norwegian), TD (translated German), N (Norwegian in the original text), G (German in the original text) are displayed in the references to the corpus data, e.g. in (LSC1N.5.s111) where $\mathrm{N}$ indicates that the mentioned example comes from an original Norwegian text and that the sentence was translated from this language. 
A fact that may seem relevant in this context is that in $\mathrm{N} \rightarrow \mathrm{G}$, the German sources prompted the occurrence of sentence-initial NPs in singular in translated Norwegian to a lesser extent. The value in this case was $67 \%$ as compared to $73 \%$ for the Norwegian sources that resulted in fully congruent correspondences in translated German.

Regarding the second research question: in Table 1, particular attention is drawn by the category designated as "Other" and its more specified derivative "The definite NP", the use of which may be seen as prototypical for the sentence initial position. In translations, their percentage was relatively low and pertained to ca. $12 \%(\mathrm{~N} \rightarrow \mathrm{G})$ and $4 \%(\mathrm{G} \rightarrow \mathrm{N})$. It should be also stressed that they were clearly varied. In the former case, the used correspondences were e. g., kurz, einst, zwischendurch, einmal, im selben, etc. for the German translations. In the latter, their inventory encompassed such items as e. g., noen, lenger oppe, neste, etc. for the Norwegian renditions, as the conceptualizations in (3) show.

(3)

Et øyeblikk etter var hun tilbake med en pakke i hendene.

Kurz darauf kam sie mit einem Paket zurück. JW1NS.2.1.s76

En henvisning til et oppslag på side 8 førte meg videre til neste utklipp.

Der Hinweis auf einen Artikel auf Seite acht führte mich weiter zum nächsten Ausschnitt. GS1N.4.s127

Eine ähnliche Angabe liegt von Rudolf Steiner vor.

Noe lignende har Rudolf Steiner angitt. UR1D.6.1.s73

Eine Antwort war ja oder nein,...

Svaret var ja eller nei, en ordre førte ham... SN1D.1.5.s126

In the context offered above, the most surprising fact in the conducted research was that in $\mathrm{N} \rightarrow \mathrm{G}$ the percentage of correspondences of this type in sources was clearly higher than in $\mathrm{G} \rightarrow \mathrm{N}$. In total, it pertained up to almost $20 \%$ of the collected language data. Therefore, it may be concluded that many German structures, which are very varied in form, forced or triggered the use of the singular indefinite NP in the sentence initial position in translated Norwegian. As many as $6.46 \%$ of them were classified as German definite NPs. It was also observed that the German source structure quite frequently was based on the so-called "naked" form of the 
noun (i. e., a form not including an article in singular) or a plural indefinite noun. The variety of language items used in the data is illustrated in (4a), while the particular instances of the German definite NPs triggering (or sourcing) the occurrence of sentence-initial indefinite NPs in singular in translated Norwegian are presented in (4b) below:

a)

Einmal kam Frau Wölk, die Vorzimmerdame,...

En dag kom fru Wölk, forværelsesdamen, .... DW1TN.3.s129

Manche junge Menschen haben sich und uns in den letzten Monaten gefragt, warum ...

En del unge mennesker har de siste måneder spurt seg og oss om hvorfor ... RVW1TN.9.s1

Als Aurora vier Jahre alt war, befahl ihr Josefa, einen Ring, ...

En gang da Aurora var ni år gammel, befalte Josefa henne å ta en ring ...ERH1TN. 2.s9

Ständiges Opfer kindlicher Streiche war die Hauslehrerin.

Et stadig offer for ungenes rampestreker, var huslærerinnen. ERH1TN. 2.s17

Leser unserer Tage mögen die Metapher [...] als etwas kraß empfinden, ...

En leser fra vår tid vil kanskje finne at metaforen $[\ldots]$... NE1TN. 6.56

Allzu nahe Berührung mit Sterbenden bedroht diesen Wunschtraum.

En alt for nær forbindelse med en døende truer denne ønskedrømmen. NE1TN. 3.s17

b)

die Frau aus reichem Haus soll Bälle und andere gesellschaftliche Verpflichtungen absagen.

En kvinne fra et rikere hjem må avstå fra ball og andre selskapelige forpliktelser, ... ERH1TN.4.s36

Dieser Irrtum kann sie noch teuer zu stehen kommen.

En slik uteglemmelse kan komme til å bli svært dyr. HME3TN.1.4.s75 Das Asthmakind, das nachts aufwacht, hat einen trockenen $\mathrm{Hu}-$ sten... 
Et astmatisk barn som våkner om natten, har en tørr hoste ... DN1TN.3.4.s11

With respect to the third research question, it may be concluded that the category designated in Table 1 above as "Sentence transformed" was mainly represented in $\mathrm{G} \rightarrow \mathrm{N}$, both in translations and sources $(22.44 \%$ and $16.71 \%$ of the analyzed language data), which is a striking observation in the conducted analysis. In practice, it meant that German sentences were subjected to major changes while rendered into Norwegian, and that Norwegian structures serving as sources for the translated German also caused (triggered) clear modifications in the sentence structure of this language during the translation process. The main patterns pertaining to such sentence construal are described briefly in the following part of the article.

The analysis showed that the indefinite NP in singular, distributed in the sentence opening in German, was repositioned from the left to the right, i. e., from the theme to the rheme position, in translation into Norwegian, confirming the relevance of the end-weight principle in this language. This mechanism is illustrated in (5) below. The form of the phrase was preserved in translation, yet, if a German indefinite NP was the subject, it was often changed into another, "lighter" subject (e. g., det 'it', han 'he') in translations into Norwegian.

(5)

Eine Mühle war eingezeichnet, ...

Det var tegnet inn en mølle, ... CH1D.6.s83

Eine höchst produktive Unruhe bewegt ihn.

$\underline{\text { Han }}$ drives frem av en ytterst produktiv uro ... HME3D.1.3.s15

Moreover, the German sentence initial might be accomplished by an adverbial representing settings for the described action, while the indefinite NP was postponed to the right in the Norwegian rendition, as in (6).

(6)

Eine günstigere Gelegenheit würde sich mitten im Wald und mitten in der Nacht wohl kaum bieten.

Og her, midt i skogen og midt på natta, kunne det knapt by seg en bedre anledning. ME1D.2.s56 
In some cases, the indefinite form of the phrase in German was additionally changed into definite in Norwegian translation:

(7)

Eine Brille klemmte auf seiner Stirn.

Han hadde brillene skjøvet opp i pannen. JUB1D.2.s121

The clause elements, ordered in original German texts as indefinite (new) - definite (thematic), were reorganized so that the initial part of the sentence in the Norwegian translation included thematic information expressed by the definite NP and the indefinite NP was moved to the right, as in example (8).

(8)

Eine unbehagliche Unruhe hat die Spitzen der Weltpolitik erfaßt. Verdenspolitikkens topper er grepet av en ubehagelig uro. HPMHS1D.2.5.s93

This type of change, implying progress from definite to indefinite in the Norwegian translations, may be explained as a quest to create "an apparently smoother information structure" in the sentence [Hasselgård, 2018, p. 108].

The changes applied by the translators in their German-to-Norwegian renditions were also more complex and pertained to the preferred ways of content construal in both languages. The nominal style in original German texts was changed to a more analytical verbal style of expression in Norwegian translations, as in (9) below.

(9)

Eine Verzögerung ergab sich, welche den Anwesenden aber recht zu sein schien ...

Det ble sent, hvilket ingen av de tilstedeværende lot til å bry seg om ... PH1D.1.s324

The same types of sentence transformations were observed in sources in $\mathrm{G} \rightarrow \mathrm{N}$. A more analytical Norwegian sentence (based on the communicative principle of the end-focus where newly-introduced elements are placed) used to be transformed by moving the indefinite NP to the 
sentence initial position in translated German. Here too, the information from the right in Norwegian was postponed to the left in German. This type of translational move is illustrated in (10).

Der er ei svart katt.

Eine schwarze Katze gibt es. HW2TDS.1.4.s263

Det sto ei lita kone på en steinskigard, ...

Eine kleine Frau stand da auf einem Steinwall. DG1TD.2.s156

Men jeg så ingen utvei.

Einen Ausweg aber sah ich nicht. DG1TD.2.s238

This pattern of sentence construal in translated German was apparent in the case of renditions of Norwegian cleft sentences. In Norwegian, the indefinite NP was placed on the right and rhematized in a cleft sentence - something that is typical for this language. In translated German, on the contrary, it occurred as the sentence opening and was construed as thematic and accessible for the addressee, as in (11).

Det er en forpint Mats som spør om han kan få lov å sove hos meg. Ein verquälter Mats fragt, ob er wohl bei mir übernachten darf. CL1TD.1.3.3.s4

Finally, the examples in (12) below show how the analytical verbal style of expression preferred in Norwegian was transformed into the German nominal style, in which information is conceived by the use of (sometimes very complex) NPs and an indefinite NP in the sentence initial position does not seem unusual.

(12)

Ved å se dette problemet i dets historiske opprinnelse vil vi således kunne få en bedre forståelse av disse konfliktene.

Eine Rekonstruktion der Entstehungsgeschichte dieses Problemes erleichtert uns dessen Verständnis. HH1TD.2.3.s91

As the examples presented in (10)-(12) above indicate, a preference for sentence initial notional subjects (even though they are indefinite) in German has also been confirmed [cf. Data-Bukowska, 2020]. 


\section{CONCLUSIONS}

The main aim of the present study was to find out to what extent in Norwegian-to-German and German-to-Norwegian corpus data sentence-initial NPs in singular were subjected to conceptual "copying", for the purpose of verifying the hypothesis about the universality of literal translation. To achieve this goal, the phenomenon was referred to the framework of the gravitational pull hypothesis that made it possible to cast new light on word-for-word rendition and relate it to more complex cognitive processes affecting translation.

It may be concluded that the analysis generally supported the literal translation hypothesis. The singular indefinite NPs in the sentence initial position (seen as highly salient linguistic structures in both languages) were translated into German and Norwegian literally. This procedure was applied in over $70 \%$ of the analyzed corpus data - a fact indicating that it was difficult for the translators to escape from the cognitive pull of the highly salient structures in the source language in their renditions. Moreover, no difference in the gravitational pull between Norwegian and German in the two types of data $(N \rightarrow G / G \rightarrow N)$ was revealed. Considering the use of sentence-initial indefinite NPs in singular, none of the languages under investigation influenced the target language in translation to a greater extent. This fact may indicate that, independently of the language in the original text, the influence of its structures on the target language is of similar strength. It was then confirmed that the phenomenon of literal renditions indeed is a good candidate for a translation universal.

However, taking into account the gravitational pull hypothesis in its new form allows us to reveal some new information on literal renditions in the languages under investigation. It may be added that the lower percentage of fully congruent correspondences in the German sources in $\mathrm{N} \rightarrow \mathrm{G}$ may indicate that the magnetism of the Norwegian structures (represented in translated Norwegian) may be seen as slightly lower than it is when translated German is concerned in $\mathrm{G} \rightarrow \mathrm{N}$ $(67.17 \% / 73.31 \%)$. It means, in practice, that in translated Norwegian the percentage of word-for-word rendered German indefinite NPs in the sentence initial position is lower than the percentage of such phrases in translated German, in which one can expect that a great majority of them is rooted in Norwegian phrases including the indefi- 
nite article in singular. Consequently, it implies that Norwegian may be more resistant to using sentence-initial indefinite NPs than German, or that German applies this way of content construal to a greater extent (or more willingly). The stronger cognitive force of magnetism of the German linguistic representation makes it more difficult for the translator (translating from Norwegian) to escape from the cognitive pull of highly salient representational elements (sentence-initial indefinite NPs) in the source language. Nevertheless, the links between elements in a bilingual's Norwegian / German linguistic representation pertaining to sentence-initial indefinite NPs in singular may be characterized as entrenched. The connectivity between them is clearly established, which results in the fact that the structures under discussion are frequently activated and used in renditions, independently of the language. Thus, the similarity between these languages in this area has been confirmed and may be characterized as strong. It could be mentioned alongside many other generally recognized similarities occurring between these languages, and encompassing, among other things, such linguistic phenomena as the V2 constraint, the presence of the indefinite article, etc. Thanks to the application of the gravitational pull hypothesis by Halverson in the conducted investigation, it can be concluded that Norwegian and German not only are similar with regard to the presence of the indefinite article in their language systems, but to its use in a very real text production, as well.

The investigation also revealed some other observations pertaining to the renditions of sentence-initial NPs in singular in $N \rightarrow G$ and $G \rightarrow N$. The distinguished "Other" correspondences to the phrase certainly have their roots in both systemic and stylistic differences between Norwegian and German. However, the observed change from the definite to indefinite phrase in the sentence initial position in $N \rightarrow G$ in sources $(13.43 \%)$ is difficult to explain because it is, in fact, against a widely approved communicative principle "to create an apparently smoother information structure" [Hasselgård, 2018, p. 108] as demonstrated in (8). The reason why German definite NPs may be a source for the use of sentence-initial indefinite NPs in singular in translated Norwegian requires a more thorough investigation. Generally, it may be expected that translators will rather avoid the occurrence of very untypical constructions, which clearly encompass sentence-initial indefinite NP in singular in Norwegian. 
Finally, the investigation revealed some significant differences in sentence construal between Norwegian and German. In practice, it meant that the structures of German sentences were subjected to major changes while rendered into Norwegian, and that Norwegian structures serving as sources for the translated German ones were also modified in the translation process. The inventory of such moves confirms the previously stated observation that the use of singular indefinite NPs in the sentence initial position is not only more frequent in German, but that it also is less marked (more popular, accepted, conventionally approved) than in Norwegian. The question that remains is whether such patterns may be seen as language specific, and the answer to it cannot be a definitive yes.

The analysis confirmed the findings pertaining to Norwegian from previous research focused on sentence-initial subject NPs in translation between Norwegian and English [Hasselgård, 2018]. It revealed a strong preference for the nominal style and notional subjects in German. In the same manner, a general tendency in Norwegian to favour the endweight principle, light subjects and starting the sentence with an adverbial representing settings for the described action - all applied in order to postpone the indefinite NP to the right in the sentence - was confirmed. However, it was not possible to state unequivocally that this kind of postponement was connected with the complexity of the indefinite NP. Several very complex sentence-initial German indefinite NPs were also literally rendered into Norwegian. Moreover, in the collected data for $N \rightarrow G$, numerous instances of similar changes were found, both in translations and sources. In the context presented above, some of the applied solutions appeared surprising, as illustrated in (13) below where the German source triggered moving the indefinite subject from the right to the left in the sentence in translated Norwegian.

(13)

An einer weißen Blechboje zerrte ein plumpes Boot.

En klumpet båt lå og rykket i en hvitmalt bøye. (SLE1TN.1.s352)

Therefore, it may be concluded that the distinguished patterns of content construal pertaining to sentence-initial indefinite NPs in singular are mainly based on preferences, both in Norwegian and German. Yet, in the context of the unambiguously confirmed literal translation 
hypothesis, they may be seen as additional and revealing the translator's freedom in capturing linguistic conceptualizations in cross-linguistic communication via translation.

\section{REFERENCES}

Altenberg B. Connectors and sentence openings in English and Swedish. Corpora and Cross-linguistic Research. Theory, Method, and Case Studies. Ed. Johansson S., Oksefjell S. Amsterdam: Rodopi, 1998. P. 115-144.

Chesterman A. Hypotheses about translation universals. Claims, Changes and Challenges in Translation Studies. Ed. Hansen G., Malmkjær K., Gille D. Amsterdam/Philadelphia: John Benjamins, 2004. P. 1-14.

Chesterman A. Reflections on the Literal Translation Hypothesis. Methods and Strategies of Process Research. Ed. Alvstad C., Tiselius E. Amsterdam: John Benjamins, 2011. P.23-35.

Data-Bukowska E. Do translators get attached to constructions? On the pivotal role of the Minimax strategy in translation. Linguistica Silesiana 36, 2015. P. 231-251.

Data-Bukowska E. Priming as cognitive motivation for the first translational response universal. Linguistica Silesiana 40, 2019. P. 185-204.

Data-Bukowska E. Translation as a source of information on text creation - the case of sentence openings in Norwegian and German. Biuletyn PTJ XXXVI, 2020. P.393-408.

Faarlund J. T., Lie S., Vannebo K. I. Norsk referansegrammatikk. Oslo: Universitetsforlaget, 2002. $1223 \mathrm{p}$.

Filipović L. Efficiency of the bilingual mind. Clues from processing, memory, and second language acquisition studies. Multilingual Cognition and Language Use. Processing and typological perspectives. Ed. Filipović L., Pütz M. Amsterdam/Philadelphia: John Benjamins, 2014. P. 205-227.

Halverson S. The cognitive basis of translation universals. Target 15(2), 2003. P. 197-241.

Halverson S. Cognitive Translation Studies and the merging of empirical paradigms: The case of 'literal translation'. Translation Spaces 4 (2), 2015. P.310-340.

Halverson S. Gravitational pull in translation. Testing a revised model. Empirical Translation Studies. New Methodological and Theoretical Traditions. Ed. De Sutter G., Lefer M.-A., Delaere I. Berlin: De Gruyter, 2017. P.9-33.

Hartsuiker R. J., Pickerin M. J., Veltkamp E. Is Syntax Separate or Shared Between Languages? Cross-Linguistic syntactic Priming in Spanish-English Bilinguals. Psychological Science 15(6), 2004. P. 409-414.

Hasselgård H. Sentence openings in English and Norwegian. Corpus-based studies in English. Papers from the $17^{\text {th }}$ International Conference on English Language Research on Computerized Corpora. Ed. Ljung M. Amsterdam: Rodopi, 1997. P. 3-20. 
Hasselgård H. Thematic structure in translation between English and Norwegian. Corpora and Cross-linguistic Research. Theory, Method, and Case Studies. Ed. Johansson S., Oksefjell S. Amsterdam: Rodopi, 1998. P. 145-167.

Hasselgård H. Thematic choices in English and Norwegian. Functions of Language 11(2), 2004. P. 187-212.

Hasselgård H. Theme in Norwegian. Semiotics from the North: Nordic Approaches to Systemic Functional Linguistics. Ed. By Berge K. L. and Maagerø E. Oslo: Novus, 2005. P. 35-48.

Hasselgård H. Sentence-initial indefinite subjects in English and Norwegian. Corpora et Comparatio Linguarum: Textual and Contextual Perspectives. Ed. By S. O. Ebeling and H. Hasselgård. Bergen Language and Linguistics Studies 9(1), 2018. P.93-114.

Helbig G., Buscha J. Deutsche Grammatik. Ein Handbuch für den Ausländerunterricht. Leipzig: VEB Verlag Enzyklopädie, 1988. 738 p.

Henson R. Priming. Encyclopedia of Neuroscience, vol. 7. Ed. Squire L. S. London: Academic Press, 2009. P. 1055-1063.

Ivir V. Formal correspondence vs. Translation equivalence revisited. Poetics Today 2(4), 1981. P. 51-59.

Johansson S. Why change the subject? On changes in subject selection in translation from English into Norwegian. Target 16(1), 2004. P. 29-52.

Johansson S. Sentence openings in translation from English into Norwegian. Norsk lingvistisk tidsskrift 23(1), 2005. P.3-35.

Johansson S. Seeing through multilingual corpora: On the Use of Corpora in Contrastive Studies. Amsterdam: John Benjamins, 2007. 355 p.

Langacker R.W. Foundations of cognitive grammar. Volume I: Theoretical Prerequisites. Stanford: Stanford University Press, 1987. 540 p.

Levý J. Translation as a Decision Process. To Honour Roman Jakobson, vol. 2. The Hague: Mouton, 1967. P.1171-1182

Loebell H., Bock K. Structural priming across languages. Linguistics 41 (5), 2003. P.791-824.

Malmkjær K. Semantic Change in Translation - A Cognitive Perspective. Translation and Knowledge. SSOTT IV. Ed. Gambier Y., Tommala J. Turku: University of Turku, Centre for Translation and Interpreting, 1993. P. 285-296.

Oslo Multilingual Corpus (OMC). Available at: https://tekstlab.uio.no/glossa2/ omc4 (accessed 19.07.2019).

Quirk R., Greenbaum S., Leech G., Svartvik J. A Comprehensive Grammar of the English Language. London: Longman, 1985. 1779 p.

Schaeffer M. J., Paterson K., McGowan V. A., White S. J., Malmkjær K. The Berkeley Aligner and the literal translation hypothesis. Translation in Transition: Between Cognition, Computing and Technology. Conference, Copenhagen Business School, January 30-31, 2014. P.1-10. Available at: https://www2.le.ac. $\mathrm{uk} /$ departments/npb/people/kbp3/pdf/reading-for-translation (accessed 19.07.2019). 
Schaeffer M., Carl M. Measuring the Cognitive Effort of Literal Translation Processes. Proceedings of the Workshop on Humans and Computer-assisted Translation ( $\mathrm{HaCaT}$ ). Ed. Ulrich G., Michael C., Koehn Ph., Sanchis-Trilles G., Casacuberta F., Hill R., O’Brien S. Stroudsburg, PA: Association for Computational Linguistics, 2014. P.29-37.

Tirkkonen-Condit S. The monitor model revisited: Evidence from process research. Translators' Journal 50(2), 2005. P. 405-414.

Toury G. Descriptive Translation Studies and Beyond. Amsterdam/Philadelphia: John Benjamins, 1995. $311 \mathrm{p}$.

Vinay J.-P., Darbelnet J. Comparative Stylistics of French and English: A Methodology for Translation. Amsterdam/Philadelphia: John Benjamins, 1995. 359 p.

\section{Эва Дата-Буковска}

Ягеллонский университет, Краков

\section{БУКВАЛЬНЫЙ ПЕРЕВОД В СВЕТЕ ГИПОТЕЗЫ ЯЗЫКОВОГО ТЯГОТЕНИЯ: НА МАТЕРИАЛЕ НЕОПРЕДЕЛЕННЫХ НАЧАЛЬНЫХ ИМЕННЫХ ГРУПП В ФОРМЕ ЕДИНСТВЕННОГО ЧИСЛА В ПЕРЕВОДЕ С НОРВЕЖСКОГО НА НЕМЕЦКИЙ И С НЕМЕЦКОГО НА НОРВЕЖСКИЙ}

Для цитирования: Data-Bukowska E. Literal translation in the light of the gravitational pull hypothesis: The case of sentence-initial indefinite noun phrases in singular in Norwegian-to-German and German-to-Norwegian translation // Скандинавская филология. 2021. Т. 19. Вып. 1. С. 5-29.

https://doi.org/10.21638/11701/spbu21.2021.101

Настоящая статья посвящена исследованию перевода начальных неопределенных ИГ в единственном числе в норвежско-немецком и немецко-норвежском параллельных корпусах. В ней кратко описываются соответствия таких ИГ и обусловленные переводом изменения в структуре предложений, включающих в себя эти группы. В частности, исследование сосредоточено на полностью конгруэнтных совпадениях начальных неопределенных ИГ в форме единственного числа, т. е. на тех случаях, когда структура предложения формально копируется при переводе. Выявление того, в какой степени подобные начальные элементы предложений сохраняются при переводе, служит верификации гипотезы, согласно которой буквальный перевод потенциально можно считать (каким-то образом забытой) переводческой универсалией. Исследование выполнено в рамках современной версии гипотезы тяготения Сандры Халверсон, что позволяет вписать феномен буквального перевода в контекст новейших когнитивных исследований межъязыковой коммуникации и выявить точки соприкосновения более традиционной контрастивной лингвистики с переводоведением. В целом анализ подтверждает гипотезу буквального перевода, поскольку исследуемые ИГ (классифицируемые как языковые структуры, отличающиеся высокой салиентностью), были переведены на немецкий и норвежский языки дословно более чем в $70 \%$ случаев. Таким образом, сила тяготения структур исходного текста 
к языку перевода одинакова. Также отмечается, что норвежский язык более устойчив к использованию неопределенных ИГ в начале предложения, чем немецкий; иначе говоря, что в немецком тексте подобные конструкции встречаются чаще. В более широкой перспективе результаты исследования проливают новый свет на то, насколько схожи и укоренены в реальном текстопорождении языковые паттерны использования неопределенного артикля в языковой практике перевода между норвежским и немецким языками.

Ключевые слова: буквальный перевод, гипотеза тяготения, переводческая универсалия, соответствие, неопределенный артикль.

\section{Ewa Data-Bukowska}

Assistant Professor, Jagiellonian University in Kraków, 9A, Al. Mickiewicza, Kraków, 31-120, Poland E-mail: ewa.data-bukowska@uj.edu.pl

Received: November 7, 2020 Accepted: April 16, 2021 